\title{
Osedax borings in fossil marine bird bones
}

\author{
Steffen Kiel • Wolf-Achim Kahl • James L. Goedert
}

Received: 27 September 2010 /Revised: 3 November 2010 / Accepted: 4 November 2010 /Published online: 20 November 2010

(C) The Author(s) 2010. This article is published with open access at Springerlink.com

\begin{abstract}
The bone-eating marine annelid Osedax consumes mainly whale bones on the deep-sea floor, but recent colonization experiments with cow bones and molecular age estimates suggesting a possible Cretaceous origin of Osedax indicate that this worm might be able grow on a wider range of substrates. The suggested Cretaceous origin was thought to imply that Osedax could colonize marine reptile or fish bones, but there is currently no evidence that Osedax consumes bones other than those of mammals. We provide the first evidence that Osedax was, and most likely still is, able to consume non-mammalian bones, namely bird bones. Borings resembling those produced by living Osedax were found in bones of early Oligocene marine flightless diving birds (family Plotopteridae). The species that produced these boreholes had a branching filiform root that grew to a length of at least $3 \mathrm{~mm}$, and lived in densities of up to 40 individuals per square centimeter. The inclusion of bird bones into the diet of Osedax has interesting implications for the recent suggestion of a Cretaceous origin of this worm because marine birds have existed continuously since the Cretaceous. Bird bones could have enabled this worm to survive times in the Earth's history when large marine
\end{abstract}

\author{
S. Kiel $(\square)$ \\ Geowissenschaftliches Zentrum der Universität Göttingen, \\ Goldschmidtstr. 3, \\ 37077, Göttingen, Germany \\ e-mail: skiel@uni-goettingen.de \\ W.-A. Kahl \\ Institut für Geowissenschaften, Universität Kiel, \\ Ludewig-Meyn-Str. 10, \\ 24118, Kiel, Germany \\ J. L. Goedert \\ Burke Museum, University of Washington, \\ Box 352010, Seattle, WA 98195-3010, USA
}

vertebrates other than fish were rare, specifically after the disappearance of large marine reptiles at the end-Cretaceous mass extinction event and before the rise of whales in the Eocene.

Keywords Whale fall · Bioerosion · Trace fossils . Deep sea $\cdot$ Siboglinidae $\cdot$ Micro-CT

\section{Introduction}

Osedax is a marine annelid (family Siboglinidae) that consumes bones on the seafloor (Rouse et al. 2004). Its evolutionary origin and the range of substrates that it is able to consume are still unclear (Glover et al. 2008; Jones et al. 2008; Vrijenhoek et al. 2008, 2009). Using molecular clock estimates, its origin has been linked to the Cenozoic rise of whales (Rouse et al. 2004), recently supported by the discovery of fossil traces of Osedax in Oligocene whale bones (Kiel et al. 2010). Using an alternative calibration for the molecular clock, however, a Cretaceous origin also seems possible (Vrijenhoek et al. 2009). In this case, Osedax might have consumed bones of large marine reptiles such as plesiosaurs and mosasaurs and after their extinction at the end of the Cretaceous it was suggested (Vrijenhoek et al. 2009) that bones of turtles, marine crocodiles, and perhaps large fishes could have been utilized. Although the bacterial symbionts that provide Osedax with nutrition can survive on collagen and lipids as sole carbon sources (Goffredi et al. 2007), there was no evidence so far that Osedax consumes anything other than mammalian bone. Here, we show that Osedax colonized bones of large, flightless marine birds in the early Oligocene and discuss the evolutionary implications of this discovery. 


\section{Material and methods}

Bones of two penguin-like birds (family Plotopteridae) collected from the Pysht Formation in northwestern Washington State were investigated: a partial skeleton of an unnamed species (University of Washington, Burke Museum, UWBM 86875), including femora and other fragments and a partial skeleton of Tonsala hildegardae Olson, 1980 (UWBM 86873) that includes a humeral fragment, femora, tibiotarsi, pelvis, and fragments of ribs and vertebrae (Goedert and Cornish 2002). The specimens were preserved in concretions found near the mouth of Murdock Creek along the Strait of Juan de Fuca, in Clallam County (UWBM loc. C0667). These sediments were deposited in bathyal depth on an oxygenated seafloor during the early Oligocene (Goedert et al. 1995). The bones were extracted by etching with dilute ( $10 \%$ or less) formic and acetic acid.

The X-ray microcomputed tomography scans of a vertebra with boreholes were done using the SkySkan1172 system (SkyScan, Belgium). The bone was scanned with a beam energy of $70 \mathrm{kV}$, a flux of $141 \mu \mathrm{A}$, and a copperaluminum filter at a detector resolution of $8.0 \mu \mathrm{m}$ per pixel using a 360-degree rotation with a step size of 0.75 degrees. The scan to survey the bone fragment (480 transmission images) was reconstructed in a $2,376 \times 2,668$ matrix of 1,935 slices with a resolution of $8.0 \mu \mathrm{m}$ per voxel using the SkyScan software NRecon running on a cluster of three networked PCs. The program uses a modified Feldkamp algorithm. The segmentation of bone and boreholes was done with the SkyScan software CT Analyser. For the study of cavity morphology details, a volume of interest in a $511 \times 547$-matrix of 314 slices was chosen. Visualization of the 3D models was done by the SkyScan software CTvol.

\section{Results}

Many of the bones of UWBM 86873 and 86875 show significant corrosion (Goedert and Cornish 2002), and almost all of the bones have at least a few boreholes. Protruding edges of some bones are corroded to the extent that much of the smooth surface has been corroded away, exposing the trabecular bone underneath (Fig. 1b). The bones also show scrape marks most likely produced by scavenging sharks. Boreholes are widely scattered on some of the bones, especially on the femora and tibiotarsi where they are restricted to the bone shaft and are absent from the more dense proximal and distal surfaces. The pelvis has a number of widely distributed boreholes, some in very thin bone such as portions of the ilium and ischium. A high density of boreholes (35 borings per square centimeter), some of them fused, with a maximum diameter of $0.3 \mathrm{~mm}$, was seen on the smooth surface of the micro-CT scanned vertebra of T. hildegardae (Fig. 1b). Just below the head of the femur of $T$. hildegardae, the density reaches 40 borings per square centimeter.

The micro-CT scans show that these boreholes lead into a network of cavities underneath the surface (Fig. 1d). A regular cavity of the trabecular bone was also penetrated (Fig. 1e). The surface layer above the network of cavities is often only 0.1 to $0.2 \mathrm{~mm}$ thick (Fig. 1f). Most holes on the investigated bones do not exceed $0.3 \mathrm{~mm}$ in diameter. Exceptions include one hole on the proximal end of a femur of $T$. hildegardae, which reaches nearly $1 \mathrm{~mm}$ in diameter (near top of Fig. 1a), and one hole that reaches $1.5 \mathrm{~mm}$ in diameter near the distal end of the femur (UWBM 86875). Both of these large holes are situated at the transition zone between shaft and the head.

\section{Discussion}

The boreholes and cavities documented here in bones of the early Oligocene plotopterid bird T. hildegardae resemble those in whale bones from the same strata and those produced by Osedax today (e.g., Figs. 1d; 2a in Kiel et al. 2010). Plotopterid bones have neurovascular foramina that can be of similar size as boreholes produced by Osedax, but they have smooth edges or start as a small sulcus whereas Osedax boreholes have sharp edges, as if made by a drill. Borings and cavities produced by other deep-sea invertebrates such as sipunculids, sponges, or bivalves differ in shape from Osedax borings (see discussion in Kiel et al. 2010) and from those reported here. Microbes can substantially damage bones in deep water, but their activities affect mainly the surface layer of the bone rather than the interior and individual borings are only a few micrometers in diameter (Allison et al. 1991; Kiel 2008). The borings documented here are thus interpreted as Osedax borings.

Compared to Osedax borings in Oligocene whale bones those reported here reach significantly higher densities, up to 40 borings per square centimeter in the bird femur compared to a maximum of 15.5 borings per square centimeter on a whale dentary (Kiel et al. 2010). The size of most borings in the bird bones is within the range of those on the whale bones (up to $0.45 \mathrm{~mm}$ in diameter), except for the two extremely large borings (up to $1.5 \mathrm{~mm}$ in diameter) on the bird femora. The shape of the cavities suggests that the producing Osedax species had a branching filiform root like the extant O. roseus (Rouse et al. 2008, their Fig. 4b) and the species that attacked Oligocene whale bones (Kiel et al. 2010). The maximum size of an individual specimen of Osedax in the bird bones is difficult to determine because all boreholes on the surface lead into interconnected cavities; however, an elongate tunnel 

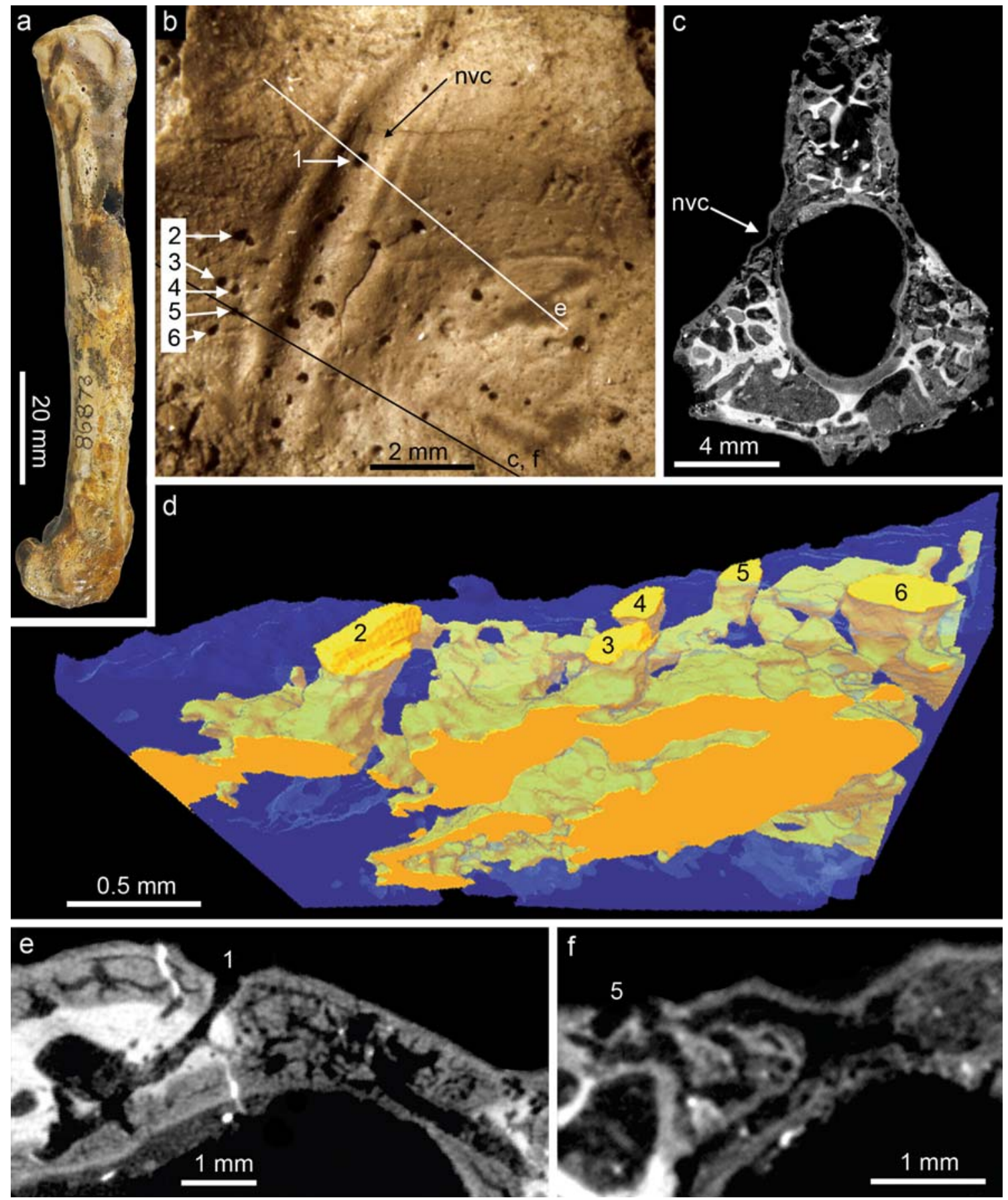

Fig. 1 Osedax borings in early Oligocene bones of the plotopterid bird T. hildegardae (UWBM 86873). a Femur showing numerous small holes, and a corrosion pit on the upper half. b Smooth lateral surface of a vertebra with a neurovascular channel $(n v c)$ in the middle and a high density of Osedax borings; numbers indicate the boreholes shown in $\mathbf{d}, \mathbf{e}$, and $\mathbf{f}$; lines indicate the positions of the micro-CT scans shown in $\mathbf{c}$, e, and f. c Reconstructed image of a micro-CT scan

(Fig. 1e) most likely produced by a single individual is $3 \mathrm{~mm}$ long. This is almost twice as large as the Osedax holes from coeval whale bones, which reach a maximum dimension of $1.7 \mathrm{~mm}$ (Kiel et al. 2010). horizontally through the vertebra, bone material (white to gray), holes and cavities (black). d Micro-CT-based rendering of the trace fossils, bone material in transparent blue, borings and cavities in yellow. e, $\mathbf{f}$ Micro-CT scan images of the vertebra, showing a relatively straight boring that penetrated a regular cavity of the trabecular bone (e) and a cavity with only a thin "roof" of bone material (f)

The trace fossils reported here provide the first evidence that Osedax was (and probably still is) able to consume non-mammalian bones. Plotopterids like T. hildegardae were large, flightless, wing-propelled diving seabirds found 
Fig. 2 Cretaceous to early Cenozoic marine bird lineages, their geologic ranges and examples of large-sized taxa. Records younger than Oligocene ( 23 mya) are not shown because whale bones where readily available for Osedax by Oligocene time. Data from Hou (1999), Galton and Martin (2002), Martin and Cordes-Person (2007), Everhart and Bell (2009), Mayr (2009) and references therein. Dagger, extinct; mya, million years ago

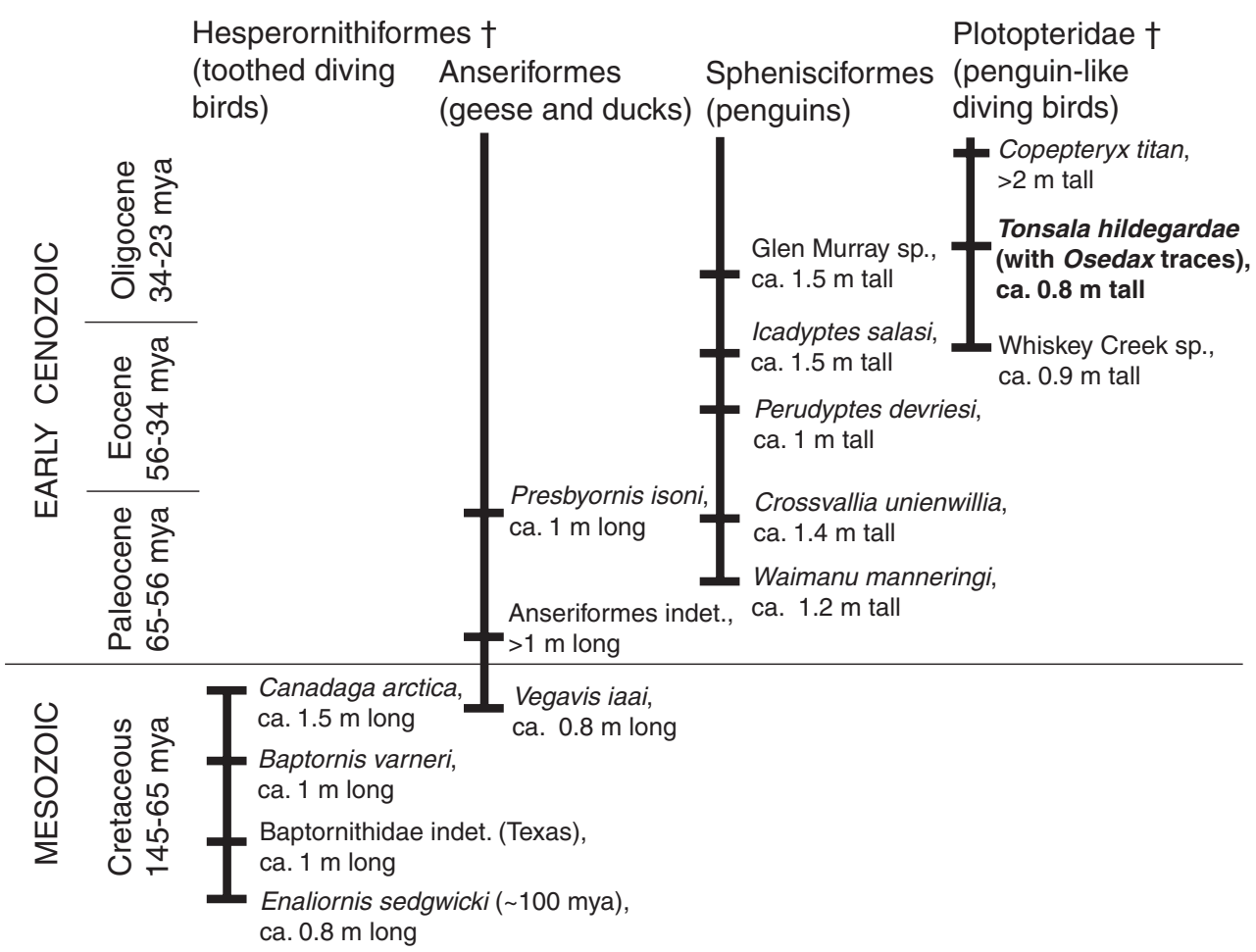

mainly in Eocene to Miocene deep-water sediments around the northern Pacific. Their bones had thick cortices and dense trabecular bone, they share several morphologic adaptations with penguins, and likely had similar foraging habits (Mayr 2009). The inclusion of bird bones into the diet of Osedax has significant evolutionary implications. A Cretaceous origin of Osedax, as suggested by some molecular clock estimates (Vrijenhoek et al. 2009), is problematic because it implies that Osedax was able to consume reptile and/or fish bones, but there is currently no evidence supporting this (Vrijenhoek et al. 2009). These food sources would have been especially important during the Paleocene when large Mesozoic marine reptiles other than turtles and crocodylians had already gone extinct and whales had not yet evolved; however, large marine birds originated in the Cretaceous, survived the end-Cretaceous mass extinction event, and existed during the recovery interval after the mass extinction (Fig. 2). If Osedax indeed originated in the Cretaceous it could have avoided extinction by using bird bones as a food source during the earliest Cenozoic, at least until whales became widely distributed in the Oligocene.

Figure 2 summarizes the geologic ranges and maximum body sizes of marine bird clades that we consider a potential food source for Osedax because they had generally thick and dense non-pneumatic bones like plotopterids (Mayr 2009). A clade of large extinct birds (with wing spans up to $6 \mathrm{~m}$ ) that is not included in this compilation is the Pelagornithidae, albatross-like marine birds with a nearly worldwide distribution from Paleocene to Pliocene time (Mayr 2009). In contrast to plotopterid bones, those of pelagornithids are extremely thin-walled and lightweight and thus may not have been attractive for Osedax. Indeed, pelagornithid bones recovered from Late Eocene to Early Miocene deep-water strata in Oregon (Goedert 1989) do not show Osedax traces (JLG, pers. obs.). Bone consumption by Osedax (the "Osedax effect") may be one reason why bird fossils are generally rare in deep marine strata; they were much smaller and could be consumed in much shorter time than whale bones. Only those with dense bones like plotopterids had a chance at surviving.

\section{Conclusions}

The boreholes documented here in fossil marine bird bones provide the first evidence that Osedax may be capable of growing on non-mammalian bones and to colonize carcasses as small as $80 \mathrm{~cm}$ in length. A possible Cretaceous origin of Osedax as suggested by molecular clock estimates was thought to require its ability to grow on fish or reptile bones, for which there is currently no evidence. The Oligocene traces documented here do not provide evidence for a Cretaceous origin of Osedax; however, marine birds have existed continuously since the Cretaceous and could thus have, in theory, provided an alternative food source for Osedax since that time. Our finding underpins the need for experimental studies on the range of substrates that Osedax is able to colonize. In 
addition, fossil bones of a wide range of vertebrates and of all sizes should be investigated for similar boreholes to clarify the age of this extraordinary bone-eating worm.

Acknowledgements We would like to thank Ron Eng, Burke Museum, Seattle, for handling the loan of specimens; John Cornish for donating UWBM 86875; Gerhard Hundertmark, Universität Göttingen, for the photography; and Bob Vrijenhoek and two anonymous reviewers for their efforts to improve this manuscript. Financial support was provided by the Deutsche Forschungsgemeinschaft grant Ki 802/6-1.

Open Access This article is distributed under the terms of the Creative Commons Attribution Noncommercial License which permits any noncommercial use, distribution, and reproduction in any medium, provided the original author(s) and source are credited.

\section{References}

Allison PA, Smith CR, Kukert H, Deming JW, Benett BA (1991) Deep-water taphonomy of vertebrate carcasses: a whale skeleton in the bathyal Santa Catalina Basin. Paleobiology 17:78-89

Everhart MJ, Bell A (2009) A hesperornithiform limb bone from the basal Greenhorn Formation (Late Cretaceous; middle Cenomanian) of north central Kansas. J Vertebr Paleontol 29:952-956

Galton PM, Martin LD (2002) Enaliornis, an Early Cretaceous hesperornithiform bird from England, with comments on other Hesperornithiformes. In: Chiappe LM, Witmer LM (eds) Mesozoic birds: above the heads of the dinosaurs. University of California Press, Berkeley/Los Angeles/London, pp 317-338

Glover AG, Kemp KM, Smith CR, Dahlgren TG (2008) On the role of bone-eating worms in the degradation of marine vertebrate remains. Proc R Soc B 275:1959-1961

Goedert JL (1989) Giant Late Eocene marine birds (Pelecaniformes: Pelagornithidae) from northwestern Oregon. J Paleontol 63:939944
Goedert JL, Cornish J (2002) A preliminary report on the diversity and stratigraphic distribution of the Plotopteridae (Pelecaniformes) in Paleogene rocks of Washington State, USA. In: Zhou Z, Zhang F (eds) 5th Symposium of the Society of Avian Paleontology and Evolution. Beijing Science Press, China, pp 63-76

Goedert JL, Squires RL, Barnes LG (1995) Paleoecology of whale-fall habitats from deep-water Oligocene rocks, Olympic Peninsula, Washington State. Palaeogeogr Palaeoclimatol Palaeoecol 118:151-158

Goffredi SK, Johnson SB, Vrijenhoek RC (2007) Genetic diversity and potential function of microbial symbionts associated with newly discovered species of Osedax polychaete worms. Appl Environ Microbiol 73:2314-2323

Hou L-H (1999) New hesperornithid (Aves) from the Canadian Arctic. Vertebrata PalAsiatica 37:228-233

Jones WJ, Johnson SB, Rouse GW, Vrijenhoek RC (2008) Marine worms (genus Osedax) colonize cow bones. Proc R Soc B 275:387-391

Kiel S (2008) Fossil evidence for micro- and macrofaunal utilization of large nekton-falls: examples from early Cenozoic deep-water sediments in Washington State, USA. Palaeogeogr Palaeoclimatol Palaeoecol 267:161-174

Kiel S, Goedert JL, Kahl W-A, Rouse GW (2010) Fossil traces of the bone-eating worm Osedax in early Oligocene whale bones. Proc Natl Acad Sci USA 107:8656-8659

Martin JE, Cordes-Person A (2007) A new species of the diving bird Baptornis (Ornithurae: Hesperornithiformes) from the lower Pierre Shale Group (upper Cretaceous) of southwestern South Dakota. Geol Soc Am Spec Pap 427:227-237

Mayr G (2009) Paleogene fossil birds. Springer, Heidelberg

Rouse GW, Goffredi SK, Vrijenhoek RC (2004) Osedax: bone-eating marine worms with dwarf males. Science 305:668-671

Rouse GW, Worsaae K, Johnson SB, Jones WJ, Vrijenhoek RC (2008) Acquisition of dwarf male "harems" by recently settled females of Osedax roseus n. sp. (Siboglinidae; Annelida). Biol Bull 214:67-82

Vrijenhoek RC, Collins P, Van Dover CL (2008) Bone-eating marine worms: habitat specialists or generalists? Proc R Soc B 275:1963-1964

Vrijenhoek RC, Johnson SB, Rouse GW (2009) A remarkable diversity of boneworms (Osedax; Siboglinidae, Annelida). BMC Biol 7:74 